\title{
Corporate Governance, Institutional Environment, Behavioral Corporate Finance and Inefficient Investment
}

\author{
Qi-An Luo, Hong-Fei Ye \\ Management School, Jinan University, Guangzhou, China \\ Email: yhf jnu@sina.com
}

Received 13 March 2015; accepted 26 June 2015; published 30 June 2015

Copyright $(\subseteq 2015$ by authors and Scientific Research Publishing Inc.

This work is licensed under the Creative Commons Attribution International License (CC BY). http://creativecommons.org/licenses/by/4.0/

(c) (i) Open Access

\begin{abstract}
This paper is the literature review of extensive literature about how inefficient investment is influenced. It discusses in three factors: corporate governance, institutional environment and behavioral corporate finance. Academics concern how the conflicts of shareholders and creditors, shareholders and managers, controlling shareholders and minority shareholders cause inefficient investment through the game. However, an enterprise is not isolated, it operates in various connections with external institutional environment. Academics interest in how formal institution such as legal environment, financial system, government intervention and informal institution like political connection impact inefficient investment. Besides, human behaviors have certain social and individual psychology background, then the crossover study of corporate finance and psychology gradually becomes a cutting-edge issue. The paper concludes the effects of investor psychology on inefficient investment by classifying psychological bias derived from investment decisions, investment execution and investment performance feedback.
\end{abstract}

\section{Keywords}

Inefficient Investment; Corporate Governance; Institutional Environment; Behavioral Corporate Finance

\section{Introduction}

The charm of investment strategies lies in involving both sources of capital and the efficiency of capital allocation. Investment creates most value of an enterprise while the uncertainty of operating environment is high and unpredictable, thus the investment efficiency has constantly caught the eyes of economists and managers. 
Inefficient investment discussing in this paper refers to Richardson's model based on the theory of free cash flow. The model reasonably estimates the normal investment along with dividing new investment into the intended investment spending and unintended investment spending. When their actual level of investment is greater or lower than the predicted value of the model, the residuals are so-called inefficient investment.

There are three basic research backgrounds for this paper. First, what factors that affect investment most have not been a consensus yet. Classic investment theories focus on how corporate governance makes a significant impact on investment efficiency from stakeholders of different contracts. Second, with further study the academic explores the roles institution played in inefficient investment, specifically involving legal environment, financial system, and social norms. Third, the conclusions of efficient investment base on efficient market hypothesis and rational person assumption. However, the real market is not so efficient and economic men are not so rational. They have tons of thoughts, emotions, and diverse targets with behaviors. Therefore psychology starts to be introduced to the behavior study of inefficient investment.

So far, micro management, macro environment, and investment psychology build up three cornerstones for the framework of investment inefficiency research. This paper will sort out relevant literature in these three areas and prospect the research trends upon them.

\section{Corporate Governance and Inefficient Investment}

Because of asymmetric information and agency problems, the game between stakeholders will deviate the investment objective from the original MM assumptions. It is common to see conclusions away from traditional MM theory when different stakeholders behave from the perspectives of maximizing their own wealth. For instance, risk and return trade-off of creditors and shareholders in investment decision-making, distribution of free cash flow and selection of short or long term projects of shareholders and managers, and "tunneling" of controlling shareholders and "free riding" of minority shareholders, are the typical violations of ideal assumptions. This paper summarizes the game motivations of investment inefficiency from the following three aspects of corporate governance.

\subsection{Shareholders-Creditors Conflicts and Inefficient Investment}

The attitudes to issuing risky bonds of shareholders and creditors depend on wealth availability. Shareholders seek to maximize net profit through business growth, while creditors hope to recover the principal and interest when the debt contract expires. Accordingly, rational choices of shareholders and creditors in the benefits and risks will lead to a conflict on investment decisions [1], mainly for asset substitution, under-investment, shareholders payment, and dilution claims [2]. This paper set forth in perspectives of inefficient investment.

Jensen, Meckling and Myers respectively proposed the possibilities of shareholder-creditors conflict affection, named asset substitution and under-investment. Jensen and Meckling's studies show that shareholders promise to invest one project when financing while they may choose a higher expected return with low stability of the other projects in practice [3]. Correspondingly, Myers said that when the expected return after paying the debt cost would be unable to fulfill of the investment costs, shareholders would reject the investment opportunities, resulting in inefficient investment [4]. However, it has positive sides. Because of relatively fixed cost of debt financing [5], this conflict could inhibit inefficient investment behavior of managers .

\subsection{Shareholders-Managers Conflicts and Inefficient Investment}

With asymmetric information and contractual incompleteness, manager's agent behavior would deviate from entrusted objectives set by shareholders. This paper will elaborate in shareholders-managers conflicts, what factors will impact the over-investment and under-investment, and how long term and short term project reflect the impact of conflicts on inefficient investment.

From objective point of view, idle cash flow after the funds required to meet all positive NPV investment projects is free cash flow, which provides an objective operational target for managers to deviate from the objective of maximizing shareholders' wealth. Managers tend to increase investment instead of putting free cash flow to reasonably pay dividends, repurchase bonds or retain for backup. With increasing control right and dependence, managers tend to use free cash flow to expand the size of investment, regardless of it is efficient [6].

From subjective points of view, managers seek an agent private gain by inefficient investment has these three motive hypotheses. First, the empire manufacturing hypothesis. Managers pursue the scale of investment rather 
than investment returns thus forming a "manager imperialism” motive. Second, the concern of manager's career and reputation hypothesis. Investment project will reveal manager's performance. Considering private gain, if the investment is insufficient, the market will focus on other operating information instead of the investment insufficiency or possible failure, which leads to under-investment. While this conservative policy may also prevent clearing up poor performing projects, which leads to over-investment. Third, the easy life hypothesis. Managers may seek more cozy individual work, luxuriously decorated office and unnecessary office expenses, which results in an under-investment in business operation.

Inefficient investment under these objective conditions and subjective motivations can be divided into longterm investments and short-sighted investment, according to the investment period. Investing long-term projects can improve the replacing difficulty of managers and specific human capital rent, thereby increasing the investment control of managers, which may result in inefficient investment [7]. On the other hand, shareholders investigate managers' effort more by earnings per share, thus managers might reduce R \& D or investment in fixed assets in order to achieve net profit expectations on nearby balance sheet date, instead of putting cash flow into the investment projects which NPV is positive, thus resulting in a short-sighted investment.

\subsection{Controlling Shareholders-Minority Shareholders Conflicts and Inefficient Investment}

The representative theory of this field that was proposed by Shleifer and Vishny is: major shareholders can improve supervision, solving the "free riding" problem under highly dispersed ownership; at the same time, controlling shareholder governance may result in infringement of the interests of minority shareholders [8]. In this paper, the study of the inefficient investment with controlling shareholders and minority shareholders conflicts considers the following three questions: 1 . How do these conflicts play the role in inefficient investment; 2 . How do other factors of corporate governance balance and coordinate in relation to the affection controlling shareholders-minority shareholders conflicts have on inefficient investment; 3 . What characteristics do inefficient investment in Chinese state-owned enterprises have?

In the 1970s, ownership structure of large companies shifted from dispersion to centralization, and then academia began to question dispersion characteristics with the empirical research. Investment efficiency caused by controlling shareholders and minority shareholders conflicts has become a mainstream research. When financing basis of equity is decentralized, the oversight cost of individual shareholder is high and investment is quite inefficient. With the increasing concentration of ownership, investment decisions began to fall into the hands of the controlling shareholder, then control motivation for private benefits expanded. In short, the change in degree of ownership concentration is a significant factor in inefficient investment caused by such conflicts.

In corporate governance structure, whether the interests of stakeholders balanced or not is the key to relieve the investment inefficiency. This paper focuses on how the interests balancing mechanism suppress inefficient investment, considering managers, creditors and shareholders' standing in different perspectives. Excessive dispersed ownership structure will strengthen the manager-agent problem, causing inefficient investment and harm the interests of shareholders. The above phenomenon will lead to equity centralization. When it reaches a certain concentration of ownership, the controlling shareholder and managers jointly control investment projects aiming at personal gains, thus the interests of minority shareholders cannot be guaranteed. Then at this point the introduction of debt financing can play a role in corporate governance, suppressing the infringement of minority shareholders' interests against controlling shareholders. An empirical study, with samples from 1999 to 2006 Chinese listed companies, testing over-investment and under-investment in the same framework, found that maintaining an appropriate concentration of ownership make over-investment weakened and under-investment enhanced. John and Senbet (1988) proved over-investment with limited liability of shareholders could be offset by the under-investment debt brings [9].

Chinese state-owned enterprises shoulder the historical tasks to maintain a public dominant status, and have a specific investment environment and investment characteristics. In equity aspect, the "dominance" makes it easier to perform as over-investment. In management aspect, the managers actively maintain the target of controlling shareholder pursuing net assets per share (rather than earnings per share), or distribute few actual profits while controlling cash flow by inefficient investment. After state-owned enterprise reform, "insider control” became a serious problem caused by "absence of owner". In credit aspect, liabilities in corporate governance with the government intervention are ineffective in corporate finance, and "soft constraints" of bank fueled inefficient investment. 


\section{Institutional Environment and Inefficient Investment}

Professor TJ Wong in Chinese University of Hong Kong pointed out that before exploring specific issues of corporate governance or accounting research, one should has a clear and macro understanding of market structure and institution system of a country. This paper adopts the “institution” definition of Douglass C. North's point of view. "Institutions are set rules and codes of conduct which requires people to obey procedures, moralities and ethics [10].” Academic circles usually classified as: formal institutions (the legal environment, the financial system, government intervention, etc.) and informal institutions (norms, customs, etc.).

\subsection{Formal Institution and the Impact on Investment}

Formal institution are codes of conduct, which are able to be clearly identified, company with a particular principal oversight and enforcement, such as all kinds of laws, regulations, policies, etc. Current research in this field focuses on how the legal environment, financial system and government intervention lead to inefficient investment.

\subsubsection{Legal Environment}

LLSV study found that variables such as the degree of investor protection and the effect of law enforcement significantly correlated with the level of development of capital markets [11]. Since then research in inefficient investment also consider the legal system as a major factor.

Law and finance theory suggests that the more effective the legal environment is, the higher level of investors protection achieves, then the more financial markets and intermediaries develop, thus contributing to business investment and economic development. Because when the law is deficient, insiders tend to "hollowed out", and the investors' defending response with information disadvantage will correspondingly increase the cost of capital or decrease money supply. High cost of financing will greatly reduce the efficiency of investment, while the full performance of the legal environment can reduce the barrier and investment inefficiency.

Specific regional studies also support the environmental impact of legal system. Cambini et al. studied European energy companies and found that in areas of poor legal environment, managers of regulated industries were more inclined to invest for personal gain [12]. Johnson et al. used Eastern Europe companies’ data and found that due to poor legal system and inadequate law enforcement, there were low willingness to invest and few over-investment to make [13]. Wurger examined 28 manufacturing companies in 65 non-socialist countries and found legal environment could limit ineffective duplication investment of free cash flow [14].

\subsubsection{Financial System}

In bank-based financial structure theory banks can promote the accumulation of capital which is critical to the capital allocation efficiency of enterprise (Hosh et al., 1991; Porter, et al., 1993). Timing and size of bank-based information disclosure benefit more on investment stability (Stiglitz, 1985; Boot et al., 1993), while competitive financial markets will easily lead to under-investment out of the "free rider" problem.

Market-based financial structure supporters believe that when companies pay the bank high cost for information of new investment, the bank will get a large share of corporate expected earnings, which will reduce the investment with high risk and high return. Although the information processing of bank is efficient, in the face of high risk in a new project the bank does not interest, easily leading to inefficient investment.

LLSV extend financial services perspective, they think the financial contract will help activate financial intermediaries and markets under a sound legal system and enforcement mechanisms [15].

\subsubsection{Government Intervention}

The role that government plays in a market economy includes night watchman, a helping hand, and a grabbing hand [16]. One advantage of the market over the government is to prohibit macro inefficient investment by the executive power. Of course, the government may also essentially become a grabbing hand due to multiple target pressure (Yuhong Lin, 2006), insufficient competition (Frydman et al., 2000), or the rent-benefits pursuit (Stigler, 1971).

Government intervention has an impact on enterprise investment in the following three ways. First, policy burdens. Having taken the government burden, companies will require compensation over policy losses, then soft budget constrain can lead to operational inefficiency and incentives invalidity. Second, financial incentives 
for local government officials. Literature suggests that local governments have the ability and motivation to reach performance goals through government intervention in enterprise investment. Third, factors of regulated industry. In order to maintain business license or excess profits, enterprises in regulated industries will pay the promotion and achievement of social objectives for government officials by project investing. Enterprises in regulated industry with government intervention tend to over-investment.

Even if the central and local government-controlled companies are part of state-owned enterprises, the differences of authority and resources result in different investment patterns. Because of the efficient revenue model, lower financing constraints, strict external supervision and improved internal governance, central enterprises lower the scale of investment inefficiency. Local state-owned enterprises bear same social responsibility with less competitive resources and environment and more pressure on performance indicators. Investment distortions are tacitly supported or chased. Non-state-owned enterprises would lead to an investment distortion or inefficiency due to less government intervention and inferior resources, but with much lower degree and tendentious manifestation of under-investment.

\subsection{Informal Institution and the Impact on Investment}

Informal system is the sum of ethics, customs, ideology and other aspects formed in human social interaction. North believes the role of informal institutions in constraint system of human behavior should not be overlooked.

Political connection concentrates the academic interests and achievements of the intersection in the field of informal system, since the 21st century scholars increasingly pay attention to political connection, and domestic and international studies have shown a universal character. The definition of political connection has not yet unified, often academia reference is Faccio's (2006) "The company's major shareholders or executives are the head of government or have close ties with government officials,” and Fan et al.'s (2007) “company CEO have worked for the central government, local government or the military."

Shleifer and Vishny (1994) by the model proved that if marginal revenue exceeds marginal cost, political connection is able to enhance business performance [17]. Subsequently, many empirical studies have found a positive impact on enterprise value with the political relevance of US public companies. However, Shleifer and Vishny's model also proved political connection, if the marginal cost was too high, would be the loss of enterprise value, and Fan et al. (2007) studied Chinese state-owned listed companies and found politically connected company's operating performance was poorer than the others [18]. But overall, supporters of the positive impact is more dominant in quantitative terms, for political connection can obtain significant benefits such as financing preferences (Johnson and Mitton, 2003; Faccio, 2007), tax concessions (Adhikari et al., 2006; Wu Wenfeng et al., 2009), investment management (Goldman, 2008; Li Shanmin et al., 2009), government subsidies (Roberts, 1990).

Specifically, government officials award government contracts with high ROI, improve tariffs on foreign competitors and reform internal regulatory to improve business investment environment (Goldman, 2008) [19]. For example, political connected companies in Germany have better ROE and ROI rates examined from 2006 to 2007 (Niessen and Ruenzi, 2010) [20]. Information asymmetry in Chinese family firms examined from 2000 to 2007 will lead to under-investment while political connection can reduce the external financing costs, improve investment efficiency and ease the under-investment (Xu et al., 2010) [21].

\section{Behavioral Corporate Finance and Inefficient Investment}

With investment theory run further, classical studies based on the "economic man" and "rational man" hypothesis have difficulty to explain for some economic events in reality. The study of investment efficiency began to develop into the intersection with psychology and behavioral corporate finance, and develop to explore the investment decisions based more on "social man" and "bounded rationality". Inefficient Investment Research will integrate variables of investors' psychology, emotion and attitude.

The psychological factors that in this paper are considered in the whole process of investment are divided into three parts: 1 . Investment decisions, including the decision-making basis (information gathering, past experience), and decision foundation (cost of capital, expected benefits and risks); 2. Investment execution (how investment policy change its route when the market information turns an unexpected change); 3. Feedback of investment effectiveness (how policy makers react and select policy trends near payback period). This article will 
focus on the mainstream research and explore how psychological bias influences the efficiency of investment in accordance with sequential procedure.

\subsection{Investment Decisions and the Impact on Investment}

By collecting, perceiving and processing information on business investment, decision-makers implement conversion of external physical signals to the brain recognizable signals. The first step is to integrate the information of new investment program and the information of past experience. This chapter firstly discusses how psychological bias in this stage — shortsighted bias and overconfidence-has an impact on investment.

Because of external pressure, self-interest motives or cognitive characteristics, investment decision-makers tend to pursue short-term interests, then easily deviate from the long-term objective of maximizing value, which is known as short-sighted bias. The first reason is in the internal governance shareholders focus on short-term performance. Bebchuk and Stole's (1993) survey found that incentive based on financial indicators might lead to short-sighted strategy, and non-financial indicators could alleviate short-sighted performance [22]. Second, in the external financial environment investors are more concerned about the short-term gains. Cadman et al. (2009) found the sample IPO companies tended to ignore share price stability in the long term because of investment institutions' short-term incentive target [23]. Third, the self-interest motivation and cognitive characteristics of decision-makers. In addition to internal and external pressures and incentives, investors meet the speculation and appear short-sighted out of age, sense of competition, etc.

Past experience is another big important cognitive factor in the investment decisions basis. Management will inertially grasp new investment based on past operational experience (Stimpert and Duhaime, 2008) [24], abandon unfamiliar projects, and retain the projects of similar experience, from which overconfidence derived. On the one hand, the overconfidence on investment earnings can lead to excessive acquisitions. Overconfidence prefers larger financial leverage and over-investment (Russo and Schoemaker, 1992), for instance, studies of the American listed companies examined from 1980 to 2002 have shown that self-attribution of overconfidence led to more frequent mergers and acquisitions. On the other hand, if decision-makers believe the stock is undervalued, they turn to endogenous equity financing and miss a good investment opportunities, which results in under-investment.

Decision foundation refers to capital cost, expected return and risk in the consideration of project, within which mental accounting and risk perception will influence the inefficient investment. The influences mental accounting have on inefficient investment mainly include the impacts of financing sources and the accounts split between the benefits and costs on investment decision. On level of risk perception, under similar conditions of risk and returns individual managers will promote the variable decisions with different reaction. The reasons can be classified as house money effect, snake bite effect, and "double or nothing" effect.

\subsection{Investment Execution and the Impact on Investment}

Enterprises devote money and time to selected investment projects after careful consideration. Afterwards, the changeful signals passing through market possibly cause "escalating commitment" out of stick-in-the mud attitude or "herd behavior" out of blind conformity.

Escalating commitment occurs when companies are abducted by sunk cost and driven from cognitive dissonance. Cognitive dissonance refers to the conflict between appreciation for their image and memories of a terrible behavior. In order to avoid psychological distress, people tend to deny or minimize any opposite sense of positive self-awareness. For deniable inefficient investment, enterprises may fall into "self-involved faith persist". Companies do not believe it is an information misjudgment, but an implementation error or inadequate resource allocation. As a result, the deficit and risks increasingly widen, creating a vicious cycle of escalating commitment.

Under the information uncertainty, managers tend to adopt the corresponding action with other group members in order to avoid bearing reputation loss with failure of individual decisions, at the same time they do not worry about being judged "fool" because of missing opportunities. Herd behavior saves information costs, reduce decision risk and maintain professional reputation, which to some extent contribute to the development of enterprises. However, if it trends to Devenow and Welch's second category of investors herd behavior--the irrational herd behavior, the inefficient investment performs as under-investment out of conservative psychology or over-investment out of blind following. Many empirical studies have explanations for it. Gilbert and Lieberman 
(1987) evaluated the investments of 24 chemical companies more than 20 years and found that minority shareholders often imitate largest shareholder's investment decisions as hitchhikers. Chaudhuri's (1997) statistics have shown the establishment of banking branch in New York from 1990 to 1995 exits herd behavior. Bo (2006) adopted the volatility of managers' market returns to measure reputation, used enterprise investments and the deviation degree of average investment at the same period within the peer industry to measure the herd behavior. He examined 564 British companies for this empirical study, then found that herding is positively correlated with the manager's reputation.

\subsection{Feedback of Investment Effectiveness and the Impact on Investment}

When the investment project is nearing completion, profit or loss has been clear and investors ability and performance will be recognized by the market. At this point investor reaction shows pride or regret company with the lessons learned in this project to serve future investment decisions. This chapter also discusses the impact of self-control psychology on investment decisions.

Pride and regret are often used to study the financial instruments investment. Seeking pride and avoiding regret, investors tend to prematurely cash profit investments and too long hold lost investments, causing inefficient investment. Pride and regret may induce overconfident and "double or nothing" effect for the next phase of investment decision.

If the project makes a profit, distribution of net profit is also related to future investment decisions. Self-control psychology refers to the conflict between two "self" in an individual for profit enjoying time. These two self are the "future planner" and "now enjoyer". Self-control psychology will determine to distribute net profit to short-term consumption or investment in the future. Short-term consumption may lead to insufficient cash flows to support positive NPV investment projects in the future, causing under-investment afterwards.

\section{Summary and Outlook}

Investment inefficiency performs in multi-level, multi-faceted dimension. If not following a main line, it is difficult to obtain essential information from complex corporate investment behaviors. The main line in this paper integrates three factors for inefficient investment. They are corporate governance, institutional environment and behavioral corporate finance.

Ideas of this paper proceed along the research history of corporate finance management. With the assumption of MM theory constantly relaxed, in the late 1970s the academic achieved the shift from focusing on external factors out of capital structure to internal factors of capital structure based on contract theory and signal theory to study enterprise investment efficiency. But whether it was a normative or empirical study, it just considered the influence of shareholders-creditors conflicts or agency costs in shareholders-managers conflicts. The late 1990s, LLSV proposed that agency problem most companies had should be a conflict between outside investors and the controlling shareholder, thus setting off an exploration on how macroscopic system such as law and finance system influenced the corporate governance and investment decision. Early 2000s, behavioral corporate finance formed a crossover study combining finance, investment with psychology. As the American financial scholar Ritter (2005) pointed out "Now one of the latest progress in the study of finance is an increasingly concern on the law and financial issues, another major advance is that many scholars is studying corporate finance in the perspective of behavior".

As for future trends, this paper believes the impact factors of inefficient investment will develop into the dynamic, segmented and data-oriented direction. First, the researches on the impact of law and finance on investment often select cross-section comparison, less considering the time series variation of the impact of investor protection and financial dynamics. Second, characteristics of law, finance and social customs are quite different in different countries, as with their accounting standards, securities regulations and tax guide, which leads to research segmentation. For instance, the research on political connection and investment efficiency of Chinese state-controlled listed companies turns to be an interesting topic. There are characteristics of emerging and transition countries in common, at the same time there are unique social and cultural characteristics of China. Future research will tend to present more diversity. Third, behavioral corporate finance will fully enrich investor psychology oriented research on decision making of investment. Empirical testing will become a trend in behavioral corporate finance study. 


\section{References}

[1] Fama, E.F. and Miller, M.H. (1972) The Theory of Finance. Holt, Rinehart and Winston, New York.

[2] Smith Jr., C. and Warner, J.B. (1979) On Financial Contracting: An Analysis of Bond Covenants. Journal of Financial Economics, 7, 117-161. http://dx.doi.org/10.1016/0304-405x(79)90011-4

[3] Jensen, M. and Meckling, W. (1976) The Theory of the Firm: Managerial Behavior, Agency Costs and Capital Structure. Journal of Finance, 3, 305-360.

[4] Myers, S. (1977) Determinants of Corporate Borrowing. Journal of Financial Economics, 5, 147-175. http://dx.doi.org/10.1016/0304-405X(77)90015-0

[5] Stulz, R. (1990) Managerial Discretion and Optional Financing Policies. Journal of Financial Economics, 26 , 3-27. http://dx.doi.org/10.1016/0304-405X(90)90011-N

[6] Murphy, K.J. (1985) Corporate Performance and Managerial Remuneration: An Empirical Analysis. Journal of Accounting and Economics, 7, 11-42.

[7] Noe, T.H. and Rebello, M.J. (1997) Renegotiation, Investment Horizons and Managerial Discretion. Journal of Business, 70, 385-407. http://dx.doi.org/10.1086/209723

[8] Shleifer, A. and Vishny, R.W. (1997) A Survey of Corporate Governance. Journal of Finance,52, 737-783. http://dx.doi.org/10.1111/j.1540-6261.1997.tb04820.x

[9] John, K. and Senbet, L. (1988) Limited Liability, Corporate Leverage, and Public Policy. New York University and University of Wisconsin-Madison, Mimeo.

[10] North, D.C. (1990) Institutions, Institutional Change and Economic Performance. Cambridge University Press, Cambridge.

[11] La Porta, R., Lopez-de-Silanes, F., Shleifer, A. and Vishny, R.W. (1998) Law and Finance. Journal of Political Economy, 106, 1113-1155. http://dx.doi.org/10.1086/250042

[12] Cambini, C. and Rondi, L. (2010) Incentive Regulation and Investment: Evidence from European Energy Utilities. Journal of Regulatory Economics, 38, 1-26. http://dx.doi.org/10.1007/s11149-009-9111-6

[13] Johnson, S., McMillan, J. and Woodruff, C. (2002) Property Rights and Finance. The American Economic Review, 92, 1335-1356. http://dx.doi.org/10.1257/000282802762024539

[14] Wurger, J. (2002) Financial Markets and the Allocation of Capital. Journal of Financial Economics, 58, 187-214. http://dx.doi.org/10.1016/S0304-405X(00)00070-2

[15] La Porta, R., Lopez-de-Silanes, F., Shleifer, A. and Vishny, R.W. (1999) The Quality of Government. Journal of Law, Economy and Organization, 15, 222-279. http://dx.doi.org/10.1093/jleo/15.1.222

[16] Shleifer, A. and Vishny, R.W. (1998) The Grabbing Hand: Government Pathologies and Their Cures. Harvard University Press, Cambridge, 1-278.

[17] Shleifer, A. and Vishny, R.W. (1994) Politicians and Firms. The Quarterly Journal of Economics, 109, 995-1025.

[18] Fan, J., Wong, T.J. and Zhang, T. (2007) Politically Connected CEOs, Corporate Governance, and Post-IPO Performance of China's Newly Partially Privatized Firms. Journal of Financial Economics, 84, 330-357. http://dx.doi.org/10.1016/j.jfineco.2006.03.008

[19] Goldman, E., So, J. and Rocholl, J. (2008) Political Connections and the Allocation of Procurement Contracts. SSRN Working Paper.

[20] Niessen, A. and Ruenzi, S. (2010) Political Connectedness and Firm Performance: Evidence from Germany. German Economic Review, 11, 441-464.

[21] Xu, N., Xu, X. and Yuan, Q. (2010) Political Connection, Financing Frictions, and Corporate Investment: Evidence from Chinese Listed Family Firms. Working Paper, Chinese Renmin University, Beijing.

[22] Bebchuk, L. and Stole, L. (1993) Do Short-Term Managerial Objectives Lead to Under- or Over-Investment in LongTerm Projects? Journal of Finance, 48, 719-729.

[23] Cadman, B.D. and Sunder, J. (2009) The Role of Investor Horizon on Compensation Horizon. Working Paper Series.

[24] Stimpert, J.L. and Duhaime, I.M. (2008) Managerial Cognition and Strategic Decision Making in Diversified Firms. SSRN Working Paper. 